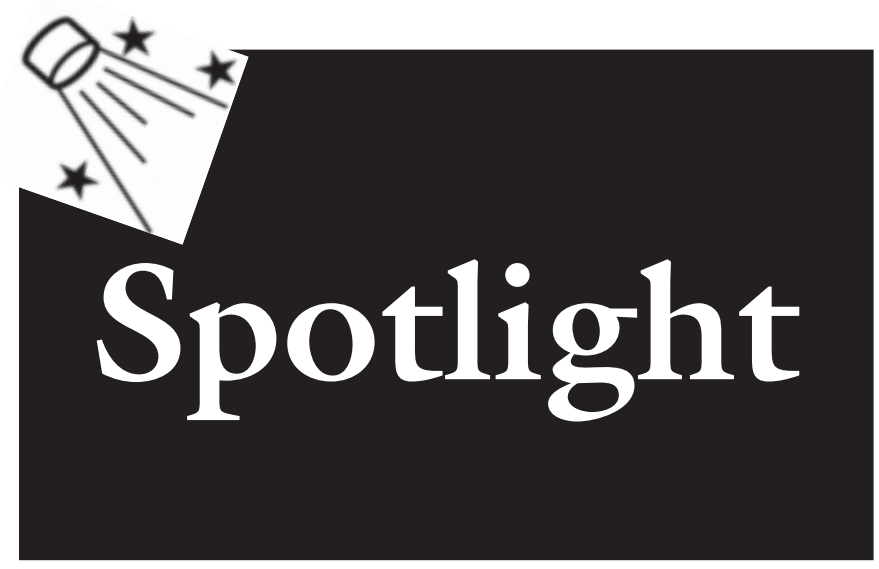

WASTES AND COMPOSTS: WHAT TO DO WITH THEM

Disposing of waste is one of modern society's greatest challenges. Organic waste by-products can be recycled for use in substrate amendments for production of horticultural crops. Chong (p. 739) describes 20 years of research evaluating nursery crops grown using hundreds of experimental substrates derived from individual or combined raw or composted farm, industrial, and consumer-waste by-products. With few exceptions, the waste materials served as acceptable to excellent container substrates. Waste materials often could be used in amounts exceeding 50\% (sometimes up to $100 \%$ ) by volume, despite initially elevated and potentially toxic levels of soluble salts in many of the substrates.

\section{HEALTHY SUBSTRATES NEED PHYSICALS TOO!}

Many studies have evaluated potential organic and mineral container substrate components for use in potting media. In the nursery industry, crops frequently remain in containers for long periods. Changes in air and water retention over extended periods have significant effect on the health and vigor of crops. Decomposition of organic components of substrates may result in excessive water content and limit air porosity. Bilderback et al. (p. 747) describe benefits related to components that break down slowly or do not decompose. Blending aggregates with organic components can decrease changes in physical properties of potting media over time.

\section{VARIABILITY AMONG AND WITHIN BRANDS OF RETAIL POTTING MEDIA}

Popular press articles report that consumers experience inconsistent and often frustrating results with retail potting media. Wiberg et al. (p. 752) found substantial variation in important physical and chemical properties among 24 different brands of retail potting media. Variability was generally greater among brands than within a brand. Label information describing media composition frequently was not consistent with measured physical and chemical properties. Only one of the 24 brands met all published standards for premium media. Results suggest better awareness of and/or adherence to standards is needed by the retail potting media industry to improve product quality and consistency.

\section{ABSCISSION AGENTS IMPROVE CAPACITY OF SWEET ORANGE MECHANICAL HARVESTING}

Mechanically harvested sweet orange acreage in Florida has slowly increased over the last decade. Abscission agents improve fruit removal via mechanical harvesting and increase potential economic gains for citrus growers. Burns et al. (p. 758) found that the use of the abscission agent CMNP in combination with shake-and-catch mechanical harvesting systems can increase harvesting capacity by reducing the time necessary to harvest each tree while maintaining high percentages of fruit removal. Provided that post-application fruit drop can be managed, cost-benefit analysis predicts that increased harvesting capacity may be the key to achieve significant cost savings with mechanical systems.

\section{SURFACE RUNOFF OF SPRINKLER IRRIGATION WATER IS MINIMAL WHEN GROUNDCLOTH IS UNDERLAIN WITH COMMON SUBSTRATES}

To better understand the fate of irrigation water in container nurseries, Million et al. (p. 772) constructed detailed platforms to measure the fraction of sprinkler irrigation water that runs off the surface of groundcloth at different slopes and with several common underlying substrates (sand, native sandy soil, and gravel). Even when tested at a high slope (11\%), runoff was less than $3 \%$ of applied water. Results also revealed that groundcloth contact with the underlying substrate becomes more important as slope increases.

\section{AUTOMATIC SYSTEM TO CONTROL PHOTOSYNTHETIC PHOTON FLUX DENSITY (PPFD) FOR LOW-LIGHT- IRRADIATION STORAGE}

Low-light-irradiation (LLI) with a light intensity at which the carbon dioxide $\left(\mathrm{CO}_{2}\right)$ exchange rate is maintained at zero during storage can suppress the change in dry weight (DW) of stored green plants. Fujiwara et al. (p. 781) developed a light-emitting-diode-LLI storage system in which the $\mathrm{CO}_{2}$ exchange rate is maintained at zero by automatically adjusting the PPFD with a proportional-integral-derivative controller. An operating test with grafted tomato plug seedlings showed that DW changes were suppressed using the system, and that the addition of blue light reduced the PPFD required to suppress the change in DW.

\section{A VIABLE SYSTEM FOR ORGANIC STRAWBERRY RUNNER PRODUCTION}

Walter et al. (p. 787) examined three indoor systems for producing strawberry runners. A suspended system where mother plants and initial runners were potted directly into the growth substrate produced about 200 plug transplants $/ \mathrm{m}^{2}$. A system using a bin on the ground produced about 100 bare-rooted transplants $/ \mathrm{m}^{2}$. Runners in the bin had higher levels of disease than in suspended systems. Field evaluation of organically and conventionally produced transplants showed generally no difference in yield or fruit quality among runner sources. However, indoor runner production allowed an earlier planting date, thereby increasing yield by $181 \mathrm{~g} /$ plant.

\section{WINE GRAPE VARIETIES VARY IN LEAF MINERAL CONCENTRATIONS}

Adaptability and mineral nutrients of grape varieties in a region should be studied before they are widely planted. Fallahi et al. (p. 825) studied cane growth, leaf size, and mineral content in six wine grape varieties under climatic conditions of intermountain western U.S. 'Sangiovese 04' and 'Merlot 01' had larger and heavier leaves and higher blade nitrogen $(\mathrm{N})$, while 'Merlot 01' and 'Chardonnay 29' had higher petiole nitrate-N than all other varieties. 'Chardonnay 29' had lower calcium and 'Sangiovese 04' had lower magnesium than other varieties. 'Chardonnay 29' had higher petiole iron than 'Barbera 02', Cabernet Sauvignon 04', and 'Sangiovese 04'.

\section{SALMONELLA SURVIVAL ON TOMATOES AND PACKINGHOUSE SURFACES}

Multi-state outbreaks of salmonellosis due to the consumption of contaminated fresh tomatoes have recently occurred in the 
U.S. Allen et al. (p. 831) investigated the survival of Salmonella artificially inoculated onto tomato and packing line surfaces when held at various temperature and relative humidity combinations over 28 days. The potential for Salmonella to persist on tomato and packing line surfaces under these environmental conditions was observed. Sanitary conditions within the packinghouse are critical in order to minimize the risk of Salmonella contamination.

\section{SANITATION SYSTEMS FOR FRESH-CUT MANGO}

Increasing demands for fresh fruits and vegetables and expansion of these markets have necessitated changes in processing larger volumes of commodities. Narciso and Plotto (p. 837) compared the efficiency of two sanitizers on whole mango fruits, and two additional sanitizers on fruit slices cut from these mangos. Microbial growth, color, and firmness were used as indicators of fruit quality. Although the sanitizers on fruit slices were successful in reducing microbial growth on cut surfaces, sanitation of the whole fruit had a direct effect on microbial populations of fruit slices cut from whole fruit.

\section{EARLY FIELD DETECTION OF BOLTING IN CELERY}

Early-season celery production may result in increased yields and prices. Unfortunately, early-season production entails a longer growing season that often starts in cooler weather conditions, which increase the risk of bolting. Jenni et al. (p. 843) developed methods by which bolting could be detected either visually at 40 days after transplanting, or microscopically at 30 days after transplanting. Early detection of bolting using the visual or microscopic criteria provided celery growers with periods of 25 and $\leq 35$ days, respectively, to consider early harvesting before the length of celery seed stems exceeded commercial standards.

\section{FLOWER COLOR PREFERENCES OF WESTERN FLOWER THRIPS (WFT)}

WFT is a major greenhouse insect pest that feeds on flowers. Blumthal et al. (p. 846) conducted experiments using various flower colors from three plant species to determine whether WFT prefer certain flower colors. The visible and near infrared reflectance spectra of the flowers tested and colored sticky cards was measured. WFT adults were most attracted to yellow transvaal daisy vs. the other flower colors tested. The yellow transvaal daisy reflectance spectrum was most similar to yellow sticky cards. Yellow transvaal daisy may be a useful trap crop for WFT.

\section{VEGETABLE OIL EMULSION INDUCES DEFOLIATION AND HELPS REDUCE APPLE SCAB}

Apple scab is a widespread disease of apple trees that often reduces marketable yield by causing extensive damage to fruit. Managing scab can be both time-consuming and costly, especially in regions where spring weather is cool and humid. Curry et al. (p. 854) applied vegetable oil emulsion (VOE) to 'Gala' and 'Fuji' apple trees after harvest. Respiration and ethylene production in leaf tissue increased within 24 hours of application and trees were defoliated within 7 days, but scab was only moderately controlled. Combinations of VOE plus lime sulfur and/or urea applied in late fall defoliated trees and controlled scab on fruit the following spring to less than $7 \%$ on 'Gala' and $0 \%$ on 'Fuji'.

\section{FLURPRIMIDOL EFFECTIVE FOR HYACINTH HEIGHT CONTROL}

Plant growth regulators often are needed in the production of pot hyacinths to avoid elongation of the flower scape during posthar- vest. Krug et al. (872) evaluated the effect of the plant growth regulator flurprimidol for height control of 'Anna Marie' hyacinth. Flurprimidol was applied as foliar sprays, substrate drenches, and preplant bulb soaks. Comparisons were made to applications of ethephon foliar sprays and paclobutrazol and uniconazole substrate drenches and preplant bulb soaks. Flurprimidol was effective at controlling plant height of 'Anna Marie' hyacinths when applied as a substrate drench or preplant bulb soak.

\section{FOOD SAFETY PROGRAM CREATES FOOD CHAIN SECURITY AND REDUCES RISK OF FOODBORNE ILLNESS}

Using a farmer/producer-level approach to food security, Osborne et al. (p. 875) have helped to create a new fresh produce food safety system throughout the southeastern U.S. System elements were developed in a multi-state, multi-disciplinary "train-thetrainer" program. Among the elements are: a grower third-party audit and certification arrangement, audit training provided by cooperative extension using cooperator-developed materials, industry acceptance of university verification of the training and certification of trained producers as "approved" suppliers, and fee-based inspections conducted by departments of agriculture in cooperating states.

\section{REGIONAL PROJECT DEMONSTRATES THE EFFECT OF VARIETY AND PLANTING SITE ON APPLE QUALITY}

Consumers and apple growers are interested in newer apple varieties with high quality and unique sensory attributes. A regional project, NE-183: The Multidisciplinary Evaluation of New Apple Cultivars, was initiated in 1995 to systematically evaluate 20 newer apple varieties across 19 planting sites in North America. Among 15 quality variables measured, Miller et al. (p. 886) found 10 variables that showed significant two-way interactions between variety and planting site. The results demonstrate that no one variety is ideally suited for all planting sites, and no planting site is ideal for maximizing the quality of all apple varieties.

\section{VEGETABLE SOYBEAN PRODUCTION IN NORTH DAKOTA}

Increases in health and soyfood markets, on both a national and international level, have spurred interest in the production of vegetable soybean. Duppong and Hatterman-Valenti (p. 896) evaluated five soybean varieties for growth and yield characteristics, and the need for irrigation in field production for North Dakota. Yields, ranging from 5773 to $10,118 \mathrm{lb} /$ acre, varied with variety and did not appear to increase with supplemental irrigation. With continued demand and consumer awareness, these vegetable soybean varieties may offer growers a new high-value alternative crop for the region.

\section{RASPBERRY AND STRAWBERRY VARIETIES TRIALED IN SOUTHERN IDAHO}

Growers in southern Idaho need profitable niche products. Robbins (p. 900) tested nine June-bearing strawberry varieties and seven floricane-fruiting (summer-bearing) raspberry varieties in USDA zone 4 conditions. Spring freezes damaged strawberry flowers. Only 'Mesabi' yielded above 6 tons/acre, a strawberry yield projected to be profitable with hand harvest; however, berry weights may have been too small for commercial production. Raspberries bloomed after the spring frosts, but cool temperatures during bloom required bumblebee colonies for pollination. All varieties yielded above 3 tons/acre, a level projected to be profitable with machine harvest. 